\title{
Editorial
}

\section{Technical and Vocational Education for Social Transformation and Justice}

\author{
Suresh Gautam Q, Tikaram Poudel O, and Prakash Kumar Paudel* \\ Kathmandu University School of Education, Lalitpur, Nepal
}

\section{Introduction}

Technical and Vocational Education and Training (TVET) in Nepal has been envisioned to enhance skills and knowledge fitting in for the contemporary market needs and increasing employability. Countries like Nepal have often been labelled as poor in term of the income and employability of their people. In this broader perspective of TVET, we argue that technical and vocational education was the agenda of metropolitan cities and urban areas to increase skills, employability and income to maintain quality of life to mitigate poverty. This neoliberal thought limited the scope of the technical and vocational education in the human life in the age of metropolitan city. The paper questions the neoliberal approaches of technical and vocational education thereby making it more inclusive to address inequalities and promote social justice against the neoliberal orientation of skills and employability which the contemporary development has proved.

The history of development has more focused on the economic enhancement of people and TVET provided the certified labourer and professionals to accelerate economic growth, business, and profits (Anderson, 2009). The classical development theorist Rostow (1959) describes the transition of society with the help of economic activities shifted from the traditional society to the age of mass consumption. In this regard, the nature of work and occupations has been changing from the simple to complex forms because of industrialization. The TVET has been deeply rooted to the agendas of nature of work related to the transformation of society. The ethos of technical and vocational education has been mainly rooted to the complex nature of work with the changing nature of industries. The job market has been shaped by the economic status of people to use innovative ways of doing work to enhance the age of mass consumption.

* Corresponding Editor.

Email: prakashpaudel@kusoed.edu.np
ISSN: 2091-0118(Print)/2091-2560(Online)

(C) 2018 The Editors.

(9) () (9) Published by Kathmandu University School of Education, Lalitpur, Nepal. 
In this regard, TVET has been powerfully affected by the neoliberal agenda of economic benefits of human beings for three reasons: a) skill-based education, b) employability, and c) job quality of the people, as Anderson (2009) claimed. In this context, preparation of workforce in the local and global market through the vocational education has just been to serve the interest of the market ignoring the core values of humanity and ecology. The dominant view today is that we have stepped on to a global knowledge economy, driven by the application of new technologies and collapsing barriers to international trade and investment, accelerating the evolutionary path from a low to a high skills economy. Becker (2002) has depicted an "age of human capital," where the prosperity of individuals and nations rests on the skills, knowledge and enterprise of all rather than a few elites that drove industrial capitalism in the twentieth century.

This view is reflected in the central role of education in national economic and social policy of Nepal. Four major assumptions mainly guide the ideas of the vocational education in Nepal: a) occupational intentions, b) occupational curriculum, c) employment, and d) schooling (Grubb \& Lazerson, 2005). However, developing workforce for the development of the country with increased income and employability in the global economic market would be a great challenge for the social transformation and justice in the society. Though the human development indicators and TVET have stronger relationships prioritizing the role of education in employment, these would not be enough to translate into equitable and just society. If the youth get access to TVET institution, their skill will likely be enhanced with necessary knowledge. Given the importance of the TVET sector and its possible contribution, universities and the Council for Technical and Vocational Education and Training (CTEVT) are established. Nevertheless, skilled human resources are yet to be adequately produced by these institutes to fulfil even the current demand.

\section{Situation of Technical and Vocational Education in Nepal}

Vocational skills are transformed from one generation to another as a close examination of traditional occupationse in every society reveals. The people developed contextual skills as per the need of survival strategies and gradually these skills kept on transferring if these skills were fount useful. However, such skills were rarely made available across communities. In the context of Nepal, after the democratic Movement of 1951, the Government of Nepal started the process of formalizing vocational skills integrating in formal education. These attempts have been foundations for the development of TVET in Nepal. The priority of the government on TVET programmes gradually increased onward and it was formally initiated with the Fourth National Plan in 1981. The expansion of TVET sector in Nepal was possible only after the establishment of CTEVT in 1989. At present, there are more than one thousand TVET institutions across the country. The CTEVT is the national leading institution for TVET sector and it is expanded in most of the palikas across the country, which has helped to establish TVET as an important sector for national development. Although TVET sector has been gradually expanding for the last few decades, expected achievement is not gained in the sector of employability.

The majority of youths who are engaged in informal skills at the local community remain without any formal vocational skills. In this sense, TVET sector is limited with metropolitan industry where it tries to link the TVET with the nature of labour market. More specifically, it serves the interest of the economic good, focusing on the economic benefits of the technical education but fails to recognize the people suffering from multiple exclusions in rural setting.

\section{Social Transformation and Justice Through TVET}

The development of the TVET sector in Nepal has been more aligned with the job market serving the needs of the production and consumption. However, TVET programmes are taken to be instrumental in minimizing social inequality and enhancing social justice. The notion of social justice, as conceptualized in this paper, is concerned with equality in use of resources among the members of a society, reducing poverty and improving living standards of people (International Forum for Social Development, 2006). However, there is an enormous gap in distribution of wealth. Moreover, access to public benefits are unequal in Nepal. Such gaps and inequalities are unjust, morally unfair, and politically unwise because our social practices do not provide our people with sufficient opportunities to engage in productive activities of their choice as they do not have required skills for personal or social rewards commensurate with their initiative, talents and efforts.

The obstacles for the social justice are inequality caused by social divisions in terms of poverty, deprivation and disadvantage. Because of geographical diversity, differences in cultural and linguistic practices, unequal distribution of resources, a large number of population has been living in the state of utter poverty and disadvantaged conditions lacking basic needs of life such as food, clothing, shelter, education and medical assistance in need. Consequently, this section of population lacks adequate resources to achieve acceptable standards of well-being and to participate in the activities of mainstream society. In democratic societies, such states of utter poverty and the condition of disadvantage is socially unacceptable and morally indefensible. This sort of inequality is covered under the dimensions of social inclusion/ exclusion discourse. The concept of social inclusion refers to the efforts to bring the deprived sections of the society into the mainstream society and to enhance opportunities of social justice. It further refers to the deviation from the principles of social justice by marginalizing certain section of the society (Dave, 2000).

As we now understand poverty and deprivation are the prime obstacles to achieving social justice through TVET. The concept of social exclusion is multidimensional in nature. It is not only about the lack of material resources that leads to poverty but about an array of matters like inadequate social participation, lack of cultural and educational capital, 
inadequate access to services and lack of power (Dave, 2000). In other words, socially excluded section of the society suffers the problems of dominance and powerlessness. In this respect, social exclusion is to be understood as a process of disempowerment and alienation from the mainstream society.

TVET can play an important role in enhancing human capability and social justice. Based on the work of Sen $(1999,2009)$, human capability approach is a means for conceptualizing the holistic human development. This approach focuses on the wellbeing of individuals, not the pursuit for financial gain. Realization of human capabilities contributes to prosperity and social justice of individuals in our social system. In this way, human capabilities are opportunities for everyday functioning of individuals.

Human capabilities such as skills and knowledge gained through education are instrumental in supporting livelihoods, generating income and reducing human insecurity. The skills gained through TVET such as literacy and numeracy that individuals apply to solve their everyday problems also relate to a wider range of cognitive development. The notions of 'agency' and 'freedom' are central to the concept of human capability which could be possible to reflect on the TVET policies in Nepal. Thus, although the development of capabilities through TVET might involve the provision of basic resources, including for example, food to meet nutritional needs, suitably prepared and motivated educators, appropriate learning materials, a relevant curriculum and an accessible built environment, capabilities also imply the freedom and opportunities that individuals are provided with through TVET to convert whatever resources they may have at their disposal into achievements or outcomes of different kinds.

The view of agency freedom has implications for the way that TVET is potentially understood and evaluated, because a key role of TVET is then to support the development of autonomy and the ability to make choices rather than simply provide individuals with the necessary resources to learn. A close look into the available literature unfolds two approaches to be dominant in conceptualizing TVET in relation to human development - the human capability approach and social justice approach. We argue that these two approaches offer insights into the role of TVET for human capability development and social justice expanding its horizon from market based skills and economy to social transformation. Building on the work of Sen (1999; 2009), we argue that TVET is instrumental in developing human capabilities leading to social justice. The concept of human capabilities is contextual because the skills useful in one particular economic social, political, environmental and cultural context may not be very functioning in other contexts. This democratic dimension of human capability approach serves the interests of marginalized groups allowing their voic to be heard in policy debates.

\section{Conclusions}

Technical and vocational education and training in Nepal started with great expectations of enhancing skills and knowledge of the youth. As a result, this contributes to the contemporary market needs and increasing employability which is not enough to envision the social justice. The establishment of CTVET was the fundamental initiation on expanding TVET sector in the country more focused on the skills and employability. Nevertheless, TVET sector in Nepal is more influenced by neoliberal idea that limited the sector within the metropolitan cities. In this broader neo-liberal perspective of TVET, we argue that TVET sector is not necessarily be the agendas ofonly metropolitan cities and urban areas. It should be accessible to all and support to increase skills, employability and income to maintain quality of life to mitigate poverty in rural subsectors as well. Hence, we argue that it would be justice to liberate technical and vocational education from the limited territory of neoliberal job market to more open and broader inclusive society. Instead, we posit that the TVET sector would enhance development when we are able to make this sector more inclusive with the idea of social justice against the neoliberal orientation of skills and employability.

\section{References}

Anderson, D. (2009). Productivism and ecologism: Changing dis/courses in TVET. In J. Fien, R. Maclean, \& M.-G. Park (Eds.), Work, learning and sustainable development (pp. 35-57). Dordrecht, The Netherlands: Springer.

Becker, G. S. (2002). The age of human capital. In E. P. Lazear (Ed.), Education in the twenty-first century (pp. 1-8). Stanford, CA: Hoover Institution Press.

Dave, M. (2000). Theories of social exclusion and the public library. In M. Dave, S. Durani, M. Dutch, R. Linley, J. Pateman, \& J. Vincent (Eds.), Open to all? The public library and social exclusion (pp. 1-15). London, England: The Council of Museums, Archives and Libraries.

Grubb, W. N., \& Lazerson, M. (2005). The education gospel and the role of vocationalism in American education. American Journal of Education, 111(3), 297-319. doi:10.1086/429112

International Forum for Social Development. (2006). Social justice in an open world: The role of the United Nations. New York, NY: United Nations.

Rostow, W. W. (1959). The stages of economic growth. The Economic History Review, $12(1), 1-16$

Sen, A. (1999). Development as freedom. New York, NY: Oxford University Press.

Sen, A. (2009). The idea of justice. London, England: Penguin. 